\title{
Stover management modifies soil organic carbon dynamics in the short-term under semiarid continuous maize
}

\author{
Jorge Álvaro-Fuentes $^{\mathrm{a}, *}$, Samuel Franco-Luesma ${ }^{\mathrm{a}}$, Victoria Lafuente ${ }^{\mathrm{a}}$, Pablo Sen ${ }^{\mathrm{b}}$, Asun Usón ${ }^{\mathrm{b}}$, \\ Carlos Cantero-Martínez ${ }^{c}$, José Luis Arrúe ${ }^{a}$ \\ ${ }^{a}$ Soil and Water Department, Estación Experimental de Aula Dei (EEAD), Spanish National Research Council (CSIC), Montañana Av. 1005, 50059 Zaragoza, Spain \\ ${ }^{\mathrm{b}}$ Agrarian and Natural Environment Sciences Department, University of Zaragoza (UZ), Carretera Cuarte s/n 22071 Huesca, Spain

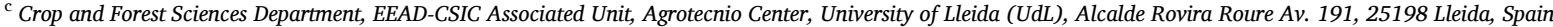

\section{A R T I C L E I N F O}

\section{Keywords:}

Irrigation method

Maize monoculture

Crop stover

No-tillage

SOC

\begin{abstract}
A B S T R A C T
In croplands, the adoption of certain management practices may increase soil organic carbon (SOC) levels. In this study, we evaluated the short-term impact of crop stover management and the interaction between crop stover and irrigation method on SOC change in a continuous maize (Zea mays L.) system in Spain. Four years after the beginning of the experiment, total SOC and C fractions (particulate organic matter carbon, POM-C; and mineralassociated organic matter carbon, Min-C) contents, SOC stocks and SOC stock changes were measured in four different soil layers $(0-5,5-10,10-25$ and $25-50 \mathrm{~cm}$ ) in an experiment with two irrigation methods (sprinkler and flood) and three stover management systems (conventional tillage with all the stover incorporated, CT; notillage maintaining the stover, NTr; and no-tillage removing the stover, NT). Stover management resulted in significant differences in SOC and POM-C but not in Min-C. In particular, NT reduced SOC and POM-C contents compared with CT and NTr (about 10 and $60 \%$, respectively). After 4 years, SOC change was not affected by the interaction between stover management and irrigation. Concurrently, both CT and NT showed SOC losses, reaching 0.11 and $1.22 \mathrm{Mg} \mathrm{ha}^{-1} \mathrm{yr}^{-1}$ in CT and NT, respectively. However, NTr showed SOC gains at a rate of $0.09 \mathrm{Mg} \mathrm{ha}^{-1} \mathrm{yr}^{-1}$. Consequently, the removal of crop stover has been demonstrated as a detrimental strategy to store SOC in the short-term in irrigated continuous maize systems.
\end{abstract}

\section{Introduction}

In croplands, different management practices have been identified to increase soil organic carbon (SOC) levels (Bai et al., 2019; Francaviglia et al., 2019). A significant number of practices that increase SOC stocks are oriented towards the increase of carbon (C) inputs. Thus, addition of exogenous C (biochar, compost, manures), crop residue management, improved fertilization or irrigation are examples of management practices which enhance SOC accrual by means of maximizing the addition of C to the soil (Paustian et al., 2016). In dryland systems, irrigation is an excellent strategy to increase SOC levels through its positive effect on crop production and, consequently, crop residues returned to the soil (Trost et al., 2013). In semiarid Spanish conditions, a significant increase in SOC levels was observed three years after the conversion from rainfed to irrigated cropland (Pareja-Sánchez et al., 2020). In this last study, an increase in $\mathrm{C}$ inputs under sprinkler irrigated conditions explained more than $70 \%$ of the variability in SOC change rates between rainfed and irrigated periods (Pareja-Sánchez et al., 2020). Similarly, in Central Great Plains (USA) greater SOC levels were observed in irrigated agroecosystems when different rainfed and irrigated fields were compared (Denef et al., 2008). Even though, the conversion to irrigated land has been evaluated in several experiments located in different parts of the world (Trost et al., 2013), the impact of the irrigation method or management on SOC changes has been less studied. In particular, we have not found any experiment in the literature studying the impact of irrigation method on SOC changes in the Mediterranean basin. Indeed, a few years ago, in a comprehensive SOC meta-analysis for the all the Mediterranean climate regions (Aguilera et al., 2013), irrigated systems were considered as a management class in the analysis but the irrigation method was not included.

Crop stover management is also an effective management practice to increase SOC levels (Aguilera et al., 2013; Stewart et al., 2018). Two recent meta-analysis have concluded that the removal of crop stover results in a general decrease in SOC (Xu et al., 2019; Wang et al., 2020).

\footnotetext{
* Corresponding author.

E-mail address: jorgeaf@eead.csic.es (J. Álvaro-Fuentes).
} 
Furthermore, the removal of crop residues not only reduces total SOC levels but also labile $\mathrm{C}$ fractions such as the particulate organic matter carbon (POM-C), particularly in high residue crops such as maize (Stewart et al., 2016; Obrycki et al., 2018). Likewise, in situations with high residue production, stover management may be linked to tillage in order to facilitate field operations (Pareja-Sánchez et al., 2019). The reduction of tillage intensity may affect SOC (Álvaro-Fuentes et al., 2014; Ogle et al., 2019) but there is still an open scientific debate about the real potential of no-tillage (NT) for sequestering C (Powlson et al., 2014; VandenBygaart, 2016). Recent global studies have concluded that the positive effect of NT on SOC sequestration depends not only on climate (Sun et al., 2020), but also on climate and soil properties (Ogle et al., 2019). Therefore, more information is still needed on the impacts of tillage systems on SOC changes under different climate and soil types. In this regard, in Mediterranean conditions, the number of studies in which the impact of tillage systems on SOC has been studied under rainfed conditions is significantly higher than under irrigated conditions (González-Sánchez et al., 2012). Furthermore, most of these studies are concentrated on the beneficial effect of NT on soil water conservation, this being an asset in dryland conditions (Lampurlanés et al., 2016).

Accordingly, the main aim of this study was to evaluate the shortterm impact of crop stover management and the interaction between irrigation method and stover management on SOC changes in a continuous maize system in semiarid conditions.

\section{Material and methods}

\subsection{Site characteristics and experimental design}

The experiment was established in 2015 in the EEAD-CSIC experimental farm located in Zaragoza, Spain $\left(41^{\circ} 42^{\prime} \mathrm{N}, 0^{\circ} 49^{\prime} \mathrm{W}, 225 \mathrm{~m}\right.$ altitude). The farm occupies 40 ha and it is entirely irrigated. The climate is Mediterranean semiarid with $14.1^{\circ} \mathrm{C}, 298 \mathrm{~mm}$ and $1243 \mathrm{~mm}$ of mean annual air temperature, mean annual precipitation and reference evapotranspiration (ETo), respectively. The soil is classified as Typical Xerofluvent (Soil Survey Staff, 2014), with a $\mathrm{pH}\left(\mathrm{H}_{2} \mathrm{O}, 1: 5\right)$ of 7.9 , electrical conductivity (1:5) of $0.31 \mathrm{dS} \mathrm{m}^{-1}$ and sand, silt and clay contents of 282,534 and $184 \mathrm{~g} \mathrm{~kg}^{-1}$, respectively, in the top $15 \mathrm{~cm}$.

In March 2015 a 0.830 ha field was divided in two identical areas. The field had been traditionally flood irrigated and intensively tilled (maintaining all the stover in the field) and for the last 10 years maize was the main crop. The two areas were used to differentiate the irrigation system. Hence, one area remained with the traditional flood irrigation system and in the adjacent area, a hand-move sprinkler irrigation system was established. In each of the two areas ( $0.415 \mathrm{ha})$, nine $6 \times 18 \mathrm{~m}$ plots were demarcated. The following three stover management treatments were laid out randomly within three blocks forming a split-block design: conventional tillage with a pass of subsoiler to $30 \mathrm{~cm}$ followed by a pass of rotary tiller and all the stover incorporated into the soil (CT); no-tillage with all the crop stover left on the soil surface (NTr); and no-tillage with all the crop stover removed from the field (NT). In this last treatment, after every season harvest, the maize stover was manually removed from the plots. From April 2015 to October 2018, four continuous maize growing seasons were established with a fivemonth fallow period (October-March) in between seasons. Maize cv. Pioneer P1785 was planted in mid-April at a density of 89,500 plants $\mathrm{ha}^{-1}$ and harvested in the first week of October. Plots were equally fertilized with $260 \mathrm{~kg} \mathrm{~N}^{-1}$ split between planting and one top dressing application at V6-V8 maize growth stage. The amount of irrigation water applied was calculated according to climate data obtained from a meteorological station located within the experimental farm and it was the same amount in all tillage treatments within a same irrigation system. The two irrigation methods presented differences in the amount of water applied and in the irrigation frequency. The flood irrigation received about $25 \%$ more water than the sprinkler irrigation (707 vs. $882 \mathrm{~mm}$ per growing season, respectively) and irrigation events occurred every 10-14 days, whereas in the sprinkler method irrigation occurred two times per week. More information about crop and irrigation management can be found in Franco-Luesma et al. (2020a, 2020b).

\subsection{Soil and crop stover sampling and $C$ analyses}

In February 2019, soil was sampled at $0-5,5-10,10-25$ and $25-50 \mathrm{~cm}$ layers. A composite sample was obtained per plot and soil layer. Once in the laboratory, soil was air dried and ground to pass a 2$\mathrm{mm}$ sieve. Soil physical fractionation was done to isolate the POM-C and Min-C fractions following the method of Cambardella and Elliot (1992). Briefly, $20 \mathrm{~g}$ of $<2 \mathrm{~mm}$ air dried soil was dispersed in $100 \mathrm{~mL}$ of $5 \mathrm{~g} \mathrm{~L}^{-1}$ sodium hexametaphosphate for $15 \mathrm{~h}$ on a reciprocal shaker. After this time, samples were passed through a $53-\mu \mathrm{m}$ sieve to separate silt + clay + Min-C $\quad(<53 \mu \mathrm{m}$ size $)$ from $>53 \mu \mathrm{m}$ size particles (sand + POM-C). The $<53 \mu \mathrm{m}$ fraction was collected in aluminium pans and oven dried at $50{ }^{\circ} \mathrm{C}$ overnight. Organic $\mathrm{C}$ concentrations of the bulk soil and the Min-C fraction were measured using a LECO analyser model RC-612 (Leco Corp., St. Joseph, MI, USA) and the POM-C was calculated by the difference between total SOC and Min-C.

Soil bulk density was measured for each soil layer using the soil cylinder method (Grossman and Reinsch, 2002). The SOC stocks were calculated considering the SOC concentration, the soil bulk density and the sampling depth. All the SOC stock values were corrected for the equivalent soil mass following the procedure explained in Ellert and Bettany (1995). As the reference soil mass was considered the CT soil management under flood irrigation as the historical management of the field. The cumulative soil mass in the $0-50 \mathrm{~cm}$ soil layer was $7911 \mathrm{Mg}$ $\mathrm{ha}^{-1}$. The SOC stock change in each treatment was calculated from the difference between the SOC stock in 2019 and the initial SOC stock measured in 2015 right before the setup of the experiment. The SOC stock measured at the beginning of the experiment for the $0-50 \mathrm{~cm}$ soil layer was $59.43 \mathrm{Mg} \mathrm{C} \mathrm{ha}^{-1}$.

In all four maize seasons, the stover yield was measured in three $2-\mathrm{m}$ rows per plot at the physiological maturity stage by separating the grain from the rest of the plant (stover). Stover subsamples were oven dried at $60{ }^{\circ} \mathrm{C}$ for $48 \mathrm{~h}$, weighed and ground. The $\mathrm{C}$ concentration was measured on a LECO analyser model Truspec CN (Leco Corp., St. Joseph, MI, USA).

\subsection{Statistical analyses}

Analyses of variance (ANOVA) were performed to evaluate the effect of the different factors (irrigation, stover management and soil layer) and their interaction effects on the different soil variables measured. The experimental design consisted in a strip block experiment in which the stover management factor was replicated three times but the irrigation factor was not replicated. Due to the lack of replication, the irrigation factor was not evaluated, but the evaluation of the interaction between the irrigation method and the stover management was possible (Federer and King, 2007). In order to meet ANOVA assumptions, the homogeneity of variances was tested with the Levene test and the normality with the Kolmogorov-Smirnov test. The POM-C content was squared- transformed because it was the only measured variable that did not fulfil the normality assumption. When significant differences were found at the 0.05 or 0.10 level, the post-hoc test Fisher's Least Significant Difference (LSD) was used to compare differences among treatments. All the statistical analyses were performed with the $\mathrm{R}$ software ( $\mathrm{R}$ Core Team, 2017).

\section{Results}

The soil bulk density was affected by the stover management, the soil depth and the interaction between irrigation and stover management (data not shown). In both irrigation methods, soil bulk density increased with soil depth with the lowest soil bulk density measured in the surface soil layer (Table 1). Under both irrigation methods, with soil depth 
Table 1

Soil bulk density after four years of continuous maize as affected by stover management (CT, conventional tillage; NT, no-tillage removing the maize stover; and NTr, no-tillage retaining the maize stover) under flood and sprinkler irrigation.

\begin{tabular}{llllll}
\hline \multirow{2}{*}{ Irrigation } & Stover management & $0-5$ & $5-10$ & $10-25$ & $25-50$ \\
\hline \multirow{2nnnyy}{*}{ Flood } & & & & & \\
& $\mathrm{CT}$ & $1.35 \mathrm{ab}^{\dagger}$ & $1.39 \mathrm{bc}$ & $1.60 \mathrm{a}$ & 1.65 \\
& $\mathrm{NT}$ & $1.44 \mathrm{a}$ & $1.36 \mathrm{c}$ & $1.53 \mathrm{a}$ & 1.66 \\
& $\mathrm{NTr}$ & $1.32 \mathrm{ab}$ & $1.46 \mathrm{abc}$ & $1.60 \mathrm{a}$ & 1.63 \\
& Average & $1.37 \mathrm{~B}^{\ddagger}$ & $1.41 \mathrm{~B}$ & $1.58 \mathrm{~A}$ & $1.65 \mathrm{~A}$ \\
& & & & & \\
\multirow{5}{*}{ Sprinkler } & & & & & \\
& $\mathrm{CT}$ & $1.24 \mathrm{~b}$ & $1.50 \mathrm{ab}$ & $1.39 \mathrm{~b}$ & 1.61 \\
& $\mathrm{NT}$ & $1.39 \mathrm{ab}$ & $1.51 \mathrm{ab}$ & $1.67 \mathrm{a}$ & 1.57 \\
& NTr & $1.44 \mathrm{a}$ & $1.53 \mathrm{a}$ & $1.64 \mathrm{a}$ & 1.63 \\
& Average & $1.36 \mathrm{~B}$ & $1.52 \mathrm{~A}$ & $1.57 \mathrm{~A}$ & $1.60 \mathrm{~A}$ \\
\hline
\end{tabular}

$\dagger$ Within a soil layer, values followed by different lowercase letters are significantly different at 0.05 level.

$\ddagger$ Within an irrigation method, mean values followed by different uppercase letters are significantly different at 0.05 level.

changes from the $0-5$ to the $25-50 \mathrm{~cm}$, soil bulk density increased about 17 and $20 \%$ for sprinkler and flood, respectively (Table 1 ). There were no clear differences in soil bulk density of the soil layers due to stover management. For example, in the $0-5 \mathrm{~cm}$ soil layer, the soil bulk density in the CT under sprinkler irrigation was significantly lower than in the NT and NTr under flood irrigation and sprinkler, respectively. But, in the 5-10 cm layer, the NT under flood irrigation resulted in significantly lower soil bulk density than the NTr under sprinkler irrigation (Table 1). In the 10-25 soil layer, the CT under sprinkler irrigation had the lowest soil bulk density, and in the $25-50$ soil layer no significant differences were found (Table 1).

The SOC and POM-C contents were affected by the stover management and soil depth and the interaction between stover management and soil depth (Table 2). No-till resulted in a reduction of SOC and POMC contents compared to CT and NTr, which showed similar values (Table 2). Soil depth not only affected SOC and POM-C contents but also Min-C content. All three soil variables decreased with soil depth. Soil organic C, POM-C and Min-C contents at the $25-50 \mathrm{~cm}$ soil depth represented only the 57, 23 and $65 \%$, respectively, of that in the topsoil

\section{Table 2}

Analysis of variance of soil organic carbon (SOC), particulate organic matter C (POM-C) and mineral-associated organic matter $\mathrm{C}$ (Min-C) contents as affected by stover management (CT, conventional tillage; NT no-tillage removing the maize stover; and NTr, no-tillage retaining the maize stover) and soil layer, and the interactions between both factors and the irrigation method (Irrigation).

\begin{tabular}{lllll}
\hline Treatment & & $\begin{array}{l}\text { SOC } \\
\mathrm{g} \mathrm{C} \mathrm{kg} \mathrm{soil}^{-1}\end{array}$ & POM-C & Min-C \\
\hline Stover & $\mathrm{CT}$ & $8.85 \mathrm{a}^{\dagger}$ & $1.43 \mathrm{a}$ & 7.42 \\
& $\mathrm{NT}$ & $7.91 \mathrm{~b}$ & $0.87 \mathrm{~b}$ & 7.04 \\
& $\mathrm{NTr}$ & $8.73 \mathrm{a}$ & $1.38 \mathrm{a}$ & 7.35 \\
& & & & \\
Soil layer & $0-5$ & $11.21 \mathrm{a}$ & $2.37 \mathrm{a}$ & $8.84 \mathrm{a}$ \\
$(\mathrm{cm})$ & $5-10$ & $8.77 \mathrm{~b}$ & $1.27 \mathrm{~b}$ & $7.50 \mathrm{~b}$ \\
& $10-25$ & $7.65 \mathrm{c}$ & $0.71 \mathrm{c}$ & $6.94 \mathrm{c}$ \\
& $25-50$ & $6.35 \mathrm{~d}$ & $0.55 \mathrm{c}$ & $5.80 \mathrm{~d}$ \\
& & & & \\
ANOVA & & & $p$ values & \\
& Stover (Stv) & $<0.01$ & $<0.05$ & $\mathrm{~ns}$ \\
& Soil layer (Layer) & $<0.001$ & $<0.001$ & $<0.001$ \\
& Irrigation x Stv & $\mathrm{ns}$ & $\mathrm{ns}$ & $\mathrm{ns}$ \\
& Irrigation x Layer & $\mathrm{ns}$ & $\mathrm{ns}$ & 0.03 \\
& Stv x Layer & 0.03 & 0.04 & $\mathrm{~ns}$ \\
& Irrigation x Stv x Layer & ns & ns & ns \\
\hline
\end{tabular}

ns, non-significant.

${ }^{\dagger}$ Values followed by different letters are significantly different at 0.05 level.
(Table 2). The Min-C was also affected by the interaction between irrigation and soil depth. In general, both irrigation methods showed a decreased in Min-C with soil depth. But in the $25-50$ soil depth, the Min-C content was significantly lower under flood than under sprinkler irrigation (data not shown).

In flood irrigation, significant differences among stover management systems were only found in the $5-10 \mathrm{~cm}$ soil depth where CT presented greater SOC than NT (Fig. 1). However, in sprinkler irrigation, significant differences were only observed in the topsoil layer $(0-5 \mathrm{~cm})$ where NTr resulted in greater SOC content than NT (Fig. 1). The POM-C fraction in the $0-5 \mathrm{~cm}$ soil depth was greater in NTr than in NT under flood irrigation (Fig. 2). However, in sprinkler irrigation, stover management systems affected POM-C contents at both the 5-10 and 10-25 cm soil depths where this fraction was significantly greater in CT than in NT and NTr, respectively (Fig. 2).

The SOC stocks were affected by the stover management and soil depth, and the interactions between irrigation and soil depth and between stover management and soil depth (data not shown). For flood irrigation, significant differences among stover management systems were found in the 5-10 soil layer where NTr resulted in lower SOC stocks than CT, and in the $25-50 \mathrm{~cm}$ soil layer where NT resulted in lower SOC stocks than NTr (Fig. 3). When the entire $0-50 \mathrm{~cm}$ soil depth was considered, NT had the lowest SOC stock. Significant differences in SOC were only found in the $0-5 \mathrm{~cm}$ depth under sprinkler irrigation where SOC was significantly greater in NTr compared with NT (Fig. 3). Furthermore, in flood irrigation, significant differences existed when the entire $0-50 \mathrm{~cm}$ soil layer was considered. In this case, NTr showed significantly greater SOC stocks than NT (Fig. 3).

After 4 years of continuous maize, SOC changes in the $0-50 \mathrm{~cm}$ soil layer were only affected by the stover management and only at the 0.10 significance level ( $p$-value $=0.073)$. The CT and NT treatments showed SOC losses of -0.11 and $-1.22 \mathrm{Mg} \mathrm{ha}^{-1} \mathrm{yr}^{-1}$, respectively (Fig. 4). On the contrary, NTr accumulated SOC during the experiment at a rate of $0.09 \mathrm{Mg} \mathrm{ha}^{-1} \mathrm{yr}^{-1}$ (Fig. 4).

\section{Discussion}

Changes in soil tillage may have a significant impact on SOC changes depending on climate and soil conditions (Ogle et al., 2019). In our study, after four years, differences in SOC between tillage systems were only observed when stover was removed from the field (Table 2). The shift from CT to NTr (with both tillage systems maintaining crop stover) did not affect SOC contents. In contrast, when the shift was from CT or

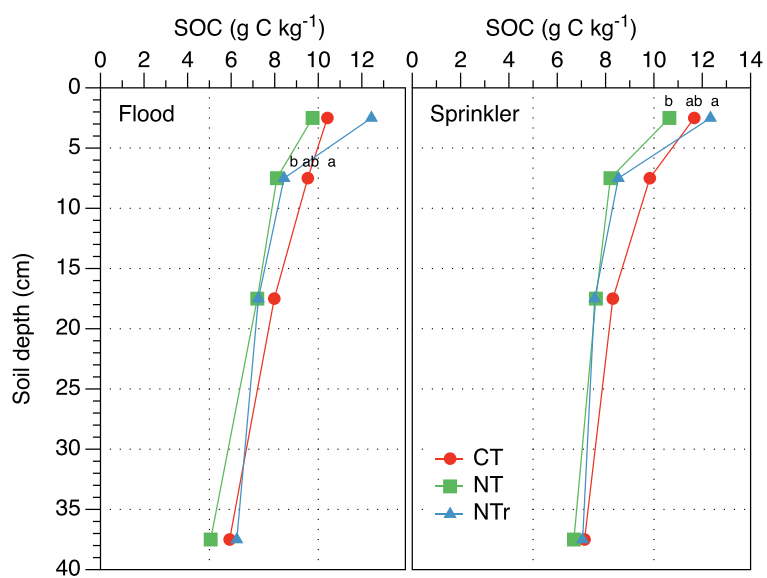

Fig. 1. Soil organic carbon (SOC) content after four years of continuous maize under flood and sprinkler irrigation methods as affected by stover management (CT, conventional tillage; NT, no-tillage removing the maize stover; and NTr, no-tillage retaining the maize stover). Within a soil layer and irrigation method, values followed by different letters are significantly different at 0.05 level. 


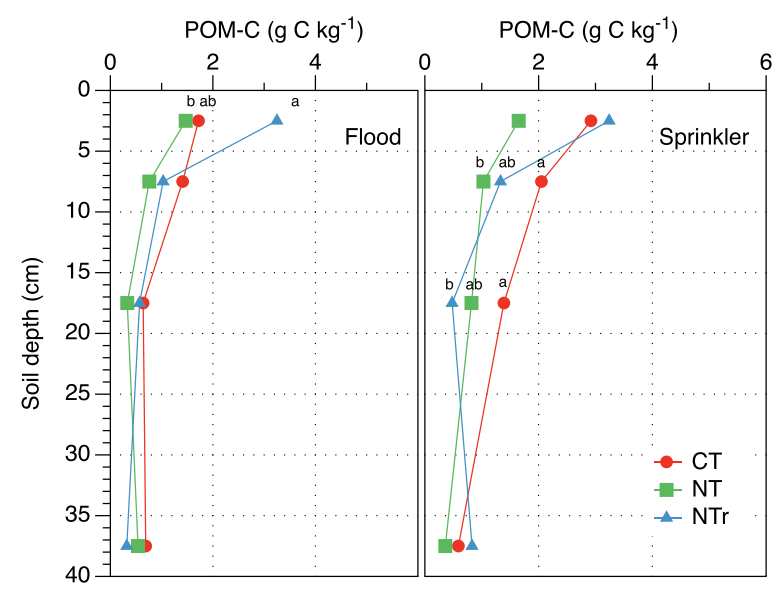

Fig. 2. Particulate organic matter C (POM-C) content after four years of continuous maize under flood and sprinkler irrigation methods as affected by stover management (CT, conventional tillage; NT, no-tillage removing the maize stover; and NTr, no-tillage retaining the maize stover). Within a soil layer and irrigation method, values followed by different letters are significantly different at 0.05 level.

NTr to NT (NT with all the stover removed) a significant decrease in SOC was observed. It is well established the positive relationship between $\mathrm{C}$ inputs and SOC gains (Virto et al., 2012; Luo et al., 2017). In our experiment, in only four years, SOC content decreased by $10 \%$ with only removing crop residues from the soil surface. In a global meta-analysis, it was estimated that SOC decrease due to maize stover removal was $8 \%$ (Xu et al., 2019). In this same study, it was observed that the greatest reduction in SOC levels were observed for short-term experiments $(<5$ years) (Xu et al., 2019). In our study, as expected, the reduction in SOC contents due to the removal of stover was mainly observed in the upper soil layers (Fig. 1), as observed in other studies (Chowdhury et al., 2015). Indeed, the analysis of variance showed that the SOC and the other two C fractions measured (POM-C and Min-C) significantly decreased with soil depth.

Besides total SOC, stover management also affected only POM-C not the Min-C fraction. As observed for total SOC, the removal of stover decreased POM-C. The POM is a C fraction derived from partially undecomposed plant-derived materials while Min-C is mostly of microbial origin (Lavallee et al., 2020). Compared with the Min-C fraction, POM-C is not associated with soil minerals, and more accessible to microbial decomposition and cycling (Cotrufo et al., 2019). Consequently, crop residue inputs directly contribute to the formation and build-up of POM-C in the topsoil which would explain the decrease found in this $\mathrm{C}$ fraction when the residue was not left on the soil in the $0-5 \mathrm{~cm}$ soil depth (Fig. 2). Several studies have also shown decreases in POM-C levels when maize stover is removed (Osborne et al., 2014; Stewart et al., 2016; Obrycki et al., 2018). Indeed, this decrease in the content of POM-C occurs rapidly as observed in two experiments located in USA where, three years after the start of the experiment, differences in POM-C between stover management treatments already existed (Sindelar et al., 2014; Ruis et al., 2018). The POM-C fraction is an early indicator of SOC changes due to changes in management (Plaza-Bonilla et al., 2014). In our study, both total SOC and POM-C contents showed significant reductions when the maize stover was removed. However, when the percentage of reduction was compared between fractions there existed differences. When the maize stover was removed the SOC decreased about $10 \%$ compared with the treatments in which the crop residues were left on the soil (NTr and CT). However, when comparing the POM-C, this proportion reached almost $38 \%$. In an experiment located under similar Mediterranean conditions, the POM-C fraction was identified as an early indicator of SOC changes when a rainfed cropping system was converted to irrigated maize (Pareja-Sánchez et al., 2020). In
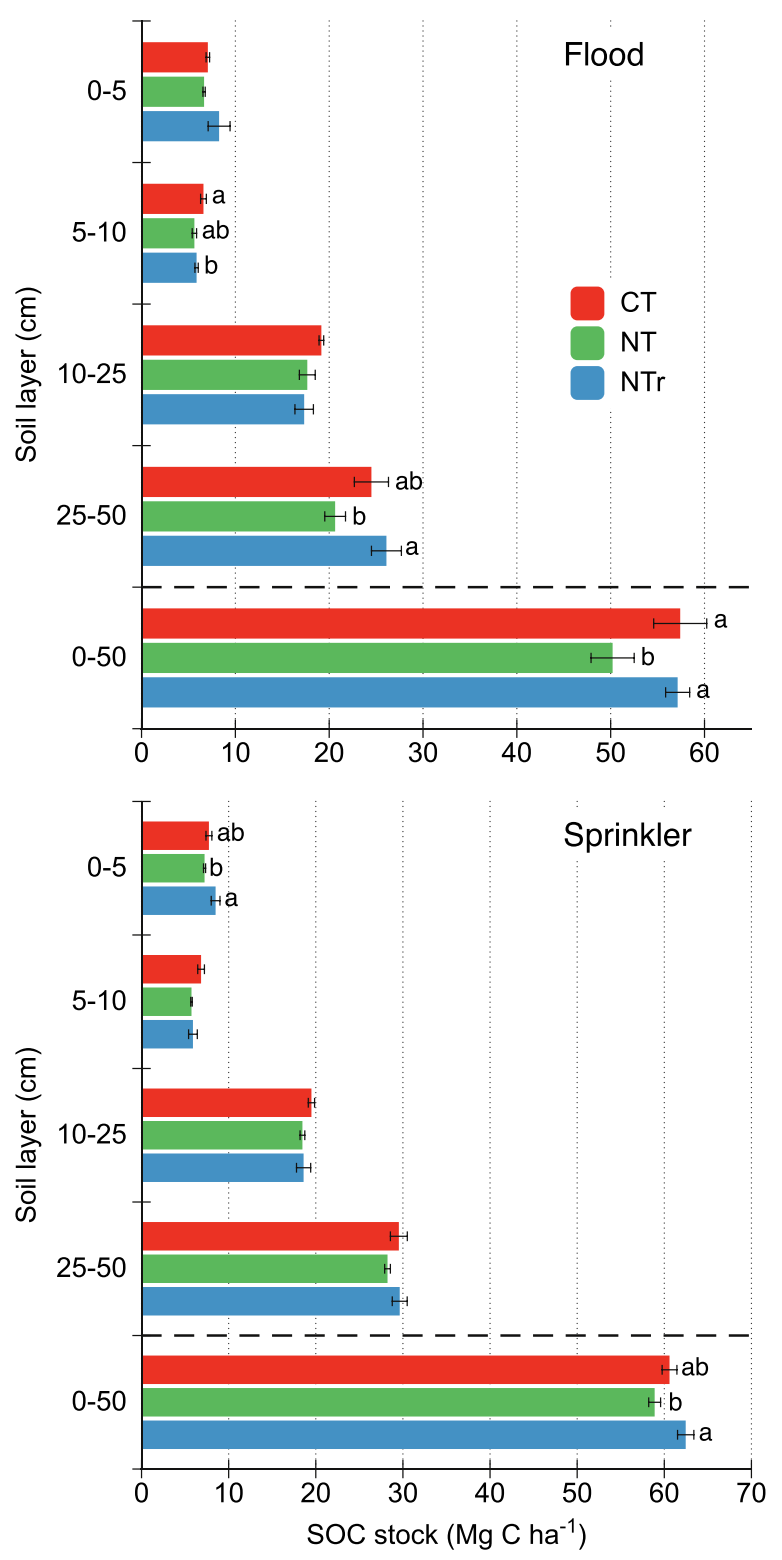

Fig. 3. Soil organic carbon (SOC) stock after four years of continuous maize under flood and sprinkler irrigation methods as affected by stover management (CT, conventional tillage; NT, no-tillage removing the maize stover; and NTr, no-tillage retaining the maize stover). Bars represent standard error. Within a soil layer and irrigation method, values followed by different letters are significantly different at 0.05 level.

particular, these same authors observed increases of about $75 \%$ in POM-C levels when rainfed systems were converted to irrigated maize systems (Pareja-Sánchez et al., 2020). Similar values of Min-C among stover management treatments were observed (Table 2) since this fraction is characterized by its inherent high mean residence time and thereby less affected by management compared with POM-C (Cambardella and Elliot, 1992).

The comparison between CT and NTr (NT maintaining maize stover) did not show differences in either SOC contents nor SOC stocks. Changes in SOC are the result of the balance between $\mathrm{C}$ inputs and losses (Paustian et al., 2016). In our case, no differences in above-ground $C$ inputs were observed among the three stover management systems tested. During the 2015-2018 period, the total stover C yield was 20.04, 18.92 and $19.15 \mathrm{Mg} \mathrm{C} \mathrm{ha}^{-1}$ in CT, NT, NTr, respectively (data not shown). Consequently, it might be assumed that, in order to compensate the balance between $\mathrm{C}$ inputs and losses, decomposition rates did not 


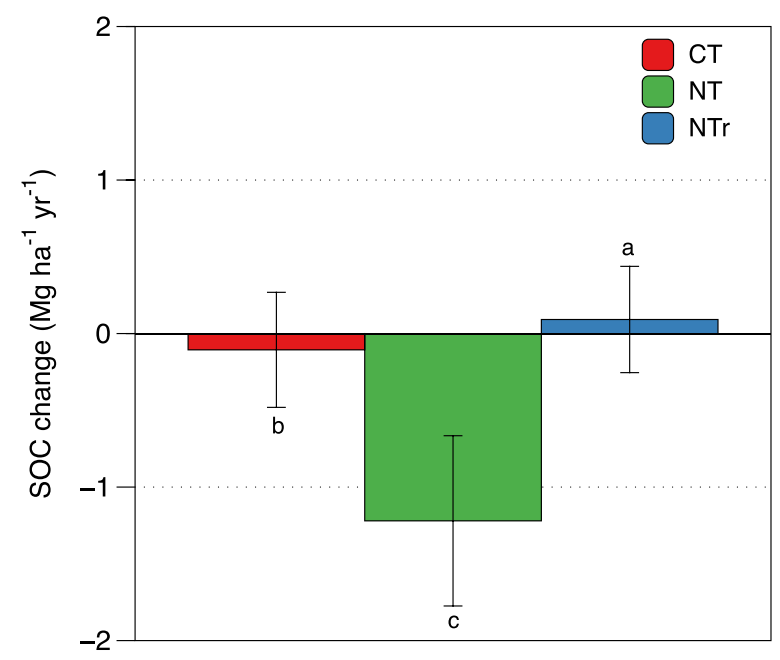

Fig. 4. Soil organic carbon (SOC) stock change after four years of continuous maize as affected by stover management (CT, conventional tillage; NT, notillage removing the maize stover; and NTr, no-tillage retaining the maize stover) Vertical bars represent standard error. Values followed by different letters are significantly different at 0.10 level.

change between CT and NTr. However, in the same experimental plots, during the 2015, 2016 and 2017 maize seasons, Franco-Luesma et al. (2020a) observed about $25 \%$ higher soil $\mathrm{CO}_{2}$ emissions under CT than under NTr which would be partly explained by a higher decomposition rate in CT. Despite this difference in soil $\mathrm{CO}_{2}$ emissions, we still found similar SOC stocks between both management systems. Thereby, we could hypothesize that the higher decomposition rates under CT might be offset by higher root C inputs in CT as observed in some studies (Barber, 1971; Li et al., 2017) or, simply, that more time needs to pass to determine whether $\mathrm{C}$ changes between tillage systems really exist (Smith, 2004). Therefore, it is important to highlight that several discussion papers have been published in the last decade questioning the potential for SOC sequestration when NT is adopted (Powlson et al., 2014; VandenBygaart, 2016). Consequently, it would be likely that after several years of the establishment of the experiment, similar SOC levels still exist between tillage systems.

During the four years of experiment, SOC stocks changed differently depending on the stover management system. However, after 4 years, SOC change was not affected by the interaction between stover management and irrigation (data not shown). The average SOC change values of the irrigation and stover management treatments presented a significant relationship with the amount of stover $\mathrm{C}$ yield produced in the 4 years (Fig. 5). But, after this time, differences between irrigation and stover management treatments were not still enough great to be statistically significant in neither yield C stover nor SOC change.

The historical crop and soil management of the field (CT maize) resulted in a slight decrease of SOC during the 4-yr period (Fig. 4). It would be expected a situation in which no changes in SOC stocks occurred, but in reality, the historical management was not in steady state conditions. The sequestration duration is controlled by several factors such as soil properties, climate, $\mathrm{C}$ inputs level and management (West and Six, 2007). In a modelling study, Álvaro-Fuentes and Paustian (2011) estimated that, under Mediterranean conditions, shifting from rainfed to irrigated in a continuous barley system would need 90 years to achieve steady state conditions.

In our study, after four years, NTr resulted in slightly gains in SOC stocks. But the most abrupt change was observed in the NT treatment with a mean SOC loss rate of $1.22 \mathrm{Mg} \mathrm{C} \mathrm{ha}^{-1} \mathrm{yr}^{-1}$. Compared to other studies in Mediterranean conditions, the annual SOC loss rate obtained in our study for NT is high (Álvaro-Fuentes and Paustian, 2011; Aguilera et al., 2013). After a shift in management, the greatest SOC change rates

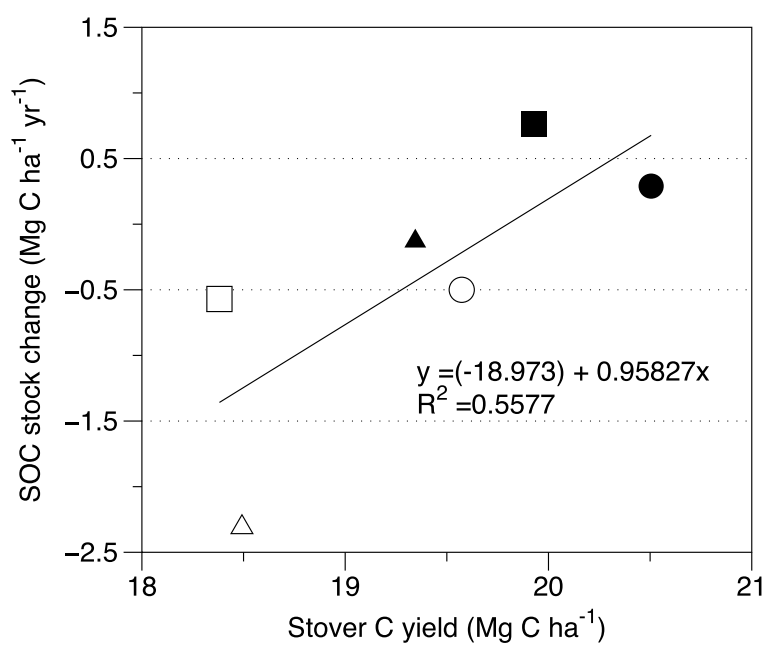

Fig. 5. Linear relationship between soil organic carbon (SOC) change and total stover C during the 2015-2018 period for different irrigation and stover management treatments: conventional tillage under flood irrigation (white circle); conventional tillage under sprinkler irrigation (black circle); no-tillage removing the maize stover under flood irrigation (white triangle); no-tillage removing the maize stover under sprinkler irrigation (black triangle); notillage retaining the maize stover under flood irrigation (white square); notillage retaining the maize stover under sprinkler irrigation (black square).

are usually observed during the first years right after the new management practice is adopted (West and Six, 2007). In Spain under rain-fed Mediterranean conditions, the greatest SOC change rates were observed 4 years after the change from CT to NT (Álvaro-Fuentes and Paustian, 2011). Consequently, in our experiment, the short period for evaluation have contributed to the high SOC losses measured in the stover removal treatment. Therefore, it would be necessary to continue evaluating the impact of these management strategies over the long-term and to identify possible future variations in the rate of SOC changes.

\section{Conclusions}

After four years, stover management has resulted in significant SOC changes in a maize monoculture system. In the two irrigation methods studied (flood and sprinkler), the removal of maize stover is a detrimental practice for SOC sequestration since, after four years, it resulted in a decrease in SOC and POM-C contents and SOC stocks compared with the maintenance of crop stover. At the same time, SOC and fraction contens and SOC stock changes were not affected by the interaction between irrigation method and stover management. The removal of crop stover has been demonstrated as a detrimental strategy to store SOC in the short-term in irrigated maize systems.

\section{Declaration of Competing Interest}

The authors report no declarations of interest.

\section{Acknowledgements}

The authors wish to thank Eva Medina and Estela Luna for laboratory and field assistance and Jorge Lampurlanés for statistical advice. Financial support of the Ministry of Economy and Competitiveness of Spain (Grant AGL2013-49062-C4-4-R), the Spanish State Agency for Research (AEI) (Grant AGL2017-84529-C3-1-R) and the European Union (FEDER funds) is gratefully acknowledged. 


\section{References}

Aguilera, E., Lassaletta, L., Gattinger, A., Gimeno, B.S., 2013. Managing soil carbon for climate change mitigation and adaptation in Mediterranean cropping systems: a meta-analysis. Agric. Ecosyst. Environ. 168, 25-36. https://doi.org/10.1016/j. agee.2013.02.003.

Álvaro-Fuentes, J., Paustian, K., 2011. Potential soil carbon sequestration in a semiarid Mediterranean agroecosystem under climate change: quantifying management and climate effects. Plant Soil 338, 261-272. https://doi.org/10.1007/s11104-010 0304-7.

Álvaro-Fuentes, J., Plaza-Bonilla, D., Arrúe, J.L., Lampurlanés, J., Cantero-Martínez, C., 2014. Soil organic carbon storage in a no-tillage chronosequence under Mediterranean conditions. Plant Soil 376, 31-41. https://doi.org/10.1007/s11104012-1167-x.

Bai, X., Huang, Y., Ren, W., Coyne, M., Jacinthe, P.-A., Tao, B., Hui, D., Yang, J., Matocha, C., 2019. Responses of soil carbon sequestration to climate-smart agriculture practices: a meta-analysis. Glob. Change Biol. 25, 2591-2606. https:// doi.org/10.1111/gcb.14658.

Barber, S.A., 1971. Effect of tillage practice on corn (Zea mays L.) root distribution and morphology. Agron. J. 63, 724-726. https://doi.org/10.2134/ agronj1971.00021962006300050020x.

Cambardella, C.A., Elliot, E.T., 1992. Particulate soil organic-matter changes across a grassland cultivation sequence. Soil Sci. Soc. Am. J. 56, 777-783. https://doi.org/ 10.2136/sssaj1992.03615995005600030017x.

Chowdhury, S., Farrell, M., Butler, G., Bolan, N., 2015. Assessing the effect of crop residue removal on soil organic carbon storage and microbial activity in a no-till cropping system. Soil Use Manage. 31, 450-460. https://doi.org/10.1111/ sum.12215.

Cotrufo, M.F., Ranalli, M.G., Haddix, M.L., Six, J., Lugato, E., 2019. Soil carbon storage informed by particulate and mineral-associated organic matter. Nat. Geosci. 12, 989-994. https://doi.org/10.1038/s41561-019-0484-6.

Denef, K., Stewart, C.E., Brenner, J., Paustian, K., 2008. Does long-term center-pivot irrigation increase soil carbon stocks in semi-arid agro-ecosystems? Geoderma 145, 121-129. https://doi.org/10.1016/j.geoderma.2008.03.002.

Ellert, B.H., Bettany, J.R., 1995. Calculation of organic matter and nutrients stored in soil under contrasting management regimes. Can. J. Soil Sci. 75, 529-538. https://doi. org/10.4141/cjss95-075.

Federer, W.T., King, F., 2007. Variations on split plot and split block experiment designs. Wiley Series in Probability and Statistics. John Wiley \& Sons.

Francaviglia, R., Di Bene, C., Farina, R., Salvati, L., Vicente-Vicente, J.L., 2019. Assessing " 4 per 1000 " soil organic carbon storage rates under Mediterranean climate: a comprehensive data analysis. Mitig. Adapt. Strat. Glob. Change 24, 795-818. https://doi.org/10.1007/s11027-018-9832-x.

Franco-Luesma, S., Cavero, J., Plaza-Bonilla, D., Cantero-Martínez, C., Arrúe, J.L., Álvaro-Fuentes, J., 2020a. Tillage and irrigation system effects on soil carbon dioxide (CO2) and methane (CH4) emissions in a maize monoculture under Mediterranean conditions. Soil Tillage Res. 196, 104488. https://doi.org/10.1016/j. still.2019.104488.

Franco-Luesma, S., Cavero, J., Plaza-Bonilla, D., Cantero-Martínez, C., Tortosa, G., Bedmar, E.J., Álvaro-Fuentes, J., 2020b. Irrigation and tillage effects on soil nitrous oxide emissions in maize monoculture. Agron. J. 112, 56-71. https://doi.org/ 10.1002/agj2.20057.

González-Sánchez, E.J., Ordóñez-Fernández, R., Carbonell-Bojollo, R., VerozGonzález, O., Gil-Ribes, J.A., 2012. Meta-analysis on atmospheric carbon capture in Spain through the use of conservation agriculture. Soil Tillage Res. 122, 52-60. https://doi.org/10.1016/j.still.2012.03.001.

Grossman, R.B., Reinsch, T.G., 2002. Bulk density and linear extensibility. In: Dane, J.H., Topp, G.C. (Eds.), Methods of Soil AnaLysis. Part 4. Physical Methods. American Society of Agronomy, Soil Science Society of America, Madison, WI, pp. 201-228.

Lampurlanés, J., Plaza-Bonilla, D., Álvaro-Fuentes, J., Cantero-Martínez, C., 2016. Longterm analysis of soil water conservation and crop yield under different tillage systems in Mediterranean rainfed conditions. Field Crops Res. 189, 59-67. https:// doi.org/10.1016/j.fcr.2016.02.010.

Lavallee, J., Soong, J.L., Cotrufo, M.F., 2020. Conceptualizing soil organic matter into particulate and mineral-associated forms to address global change in the 21st century. Glob. Change Biol. 26, 261-273. https://doi.org/10.1111/gcb.14859.

Li, H., Mollier, A., Ziadi, N., Shi, Y., Parent, L.-E., Morel, C., 2017. The long-term effects of tillage practice and phosphorus fertilization on the distribution and morphology of corn root. Plant Soil 412, 97-114. https://doi.org/10.1007/s11104-016-2925-y.

Luo, Z., Feng, W., Luo, Y., Baldock, J., Wang, E., 2017. Soil organic carbon dynamics jointly controlled by climate, carbon inputs, soil properties and soil carbon fractions. Glob. Change Biol. 23, 4430-4439. https://doi.org/10.1111/gcb.13767.
Obrycki, J.F., Karlen, D.L., Cambardella, C.A., Kovar, J.L., Birrell, S.J., 2018. Corn stover harvest, tillage, and cover crop effects on soil health indicators. Soil Sci. Soc. Am. J. 82, 910-918. https://doi.org/10.2136/sssaj2017.12.0415.

Ogle, S.M., Alsaker, C., Baldock, J., Bernoux, M., Breidt, F.J., McConkey, B., Regina, K., Vazquez-Amabile, G.G., 2019. Climate and soil characteristics determine where NoTill management can store carbon in soils and mitigate greenhouse gas emissions. Sci. Rep. 9, 11665. https://doi.org/10.1038/s41598-019-47861-7.

Osborne, S.L., Johnson, J.M.F., Jin, V.L., Hammerbeck, A.L., Varvel, G.E., Schumacher, T.E., 2014. The impact of corn residue removal on soil aggregates and particulate organic matter. Bioenerg. Res. 7, 559-567. https://doi.org/10.1007/ s12155-014-9413-0.

Pareja-Sánchez, E., Plaza-Bonilla, D., Álvaro-Fuentes, J., Cantero-Martínez, C., 2019. Is it feasible to reduce tillage and $\mathrm{N}$ use while improving maize yield in irrigated Mediterranean agroecosystems? Eur. J. Agron. 109, 125919. https://doi.org/ 10.1016/j.eja.2019.125919.

Pareja-Sánchez, E., Cantero-Martínez, C., Álvaro-Fuentes, J., Plaza-Bonilla, D., 2020. Soil organic carbon sequestration when converting a rainfed cropping system to irrigated corn under different tillage systems and N fertilizer rates. Soil Sci. Soc. Am. J. 84, 1219-1232. https://doi.org/10.1002/saj2.20116.

Paustian, K., Lehmann, J., Ogle, S., Reay, D., Robertson, G.P., Smith, P., 2016. Climatesmart soils. Nature 532, 49-57. https://doi.org/10.1038/nature17174.

Plaza-Bonilla, D., Álvaro-Fuentes, J., Cantero-Martínez, C., 2014. Identifying soil organic carbon fractions sensitive to agricultural management practices. Soil Tillage Res. 139, 19-22. https://doi.org/10.1016/j.still.2014.01.006.

Powlson, D.S., Stirling, C.M., Jat, M.L., Gerard, B.G., Palm, C.A., Sanchez, P.A., Cassman, K.G., 2014. Limited potential of no-till agriculture for climate change mitigation. Nat. Clim. Change 4, 678-683. https://doi.org/10.1038/ NCLIMATE2292.

R Core Team, 2017. R: A Language and Environment for Statistical Computing. https:// www.r-project.org/.

Ruis, S., Blanco-Caqui, H., Burr, C., Olson, B., Reiman, M., Rudnick, D., Drijber, R., Shaver, T., 2018. Corn residue baling and grazing impacts on soil carbon stocks and other properties on a haplustoll. Soil Sci. Soc. Am. J. 82, 202-213. https://doi.org/ 10.2136/sssaj2017.05.0177.

Sindelar, A.J., Lamb, J.A., Coulter, J.A., 2014. Short-term stover, tillage, and nitrogen management affect near-surface soil organic matter. Soil Sci. Soc. Am. J. 79, 251-260. https://doi.org/10.2136/sssaj2014.08.0337.

Smith, P., 2004. How long before a change in soil organic carbon can be detected? Glob. Change Biol. 10, 1878-1883. https://doi.org/10.1111/j.1365-2486.2004.00854.x.

Soil Survey Staff, 2014. Keys to Soil Taxonomy, 12th ed. USDA-Natural Resources Conservation Service, Washington, DC. pp. 306.

Stewart, C.E., Follet, R.F., Pruessner, E.G., Varvel, G.E., Vogel, K.P., Mitchell, R.B., 2016. $\mathrm{N}$ fertilizer and harvest impacts on bioenergy crop contributions to SOC. GCB Bioenergy 8, 1201-1211. https://doi.org/10.1111/gcbb.12326.

Stewart, C.E., Roosendaal, D.L., Manter, D.K., Delgado, J.A., Grosso, S.D., 2018. Interactions of stover and nitrogen management on soil microbial community and labile carbon under irrigated no-till corn. Soil Sci. Soc. Am. J. 82, 323-331. https:// doi.org/10.2136/sssaj2017.07.0229.

Sun, W., Canadell, J.G., Yu, L., Yu, L., Zhang, W., Smith, P., Fischer, T., Huang, Y., 2020. Climate drives global soil carbon sequestration and crop yield changes under conservation agriculture. Glob. Change Biol. 26, 3325-3335. https://doi.org/ 10.1111/gcb.15001.

Trost, B., Prochnow, A., Drastig, K., Meyer-Aurich, A., Ellmer, F., Baumecker, M., 2013. Irrigation, soil organic carbon and $\mathrm{N} 2 \mathrm{O}$ emissions. A review. Agron. Sustain. Dev. 33, 733-749. https://doi.org/10.1007/s13593-013-0134-0.

VandenBygaart, A.J., 2016. The myth that no-till can mitigate global climate change. Agric. Ecosyst. Environ. 216, 98-99. https://doi.org/10.1016/j.agee.2015.09.013.

Virto, I., Barré, P., Burlot, A., Chenu, C., 2012. Carbon input differences as the main factor explaining the variability in soil organic $C$ storage in no-tilled compared to inversion tilled agrosystems. Biogeochemistry 108, 17-26. https://doi.org/10.1007/ s10533-011-9600-4.

Wang, X., He, C., Liu, B., Zhao, X., Liu, Y., Wang, Q., Zhang, H., 2020. Effects of residue returning on soil organic carbon storage and sequestration rate in China's croplands: a meta-analysis. Agronomy 10, 691. https://doi.org/10.3390/agronomy10050691.

West, T., Six, J., 2007. Considering the influence of sequestration duration and carbon saturation on estimates of soil carbon capacity. Clim. Change 80, 25-41. https://doi. org/10.1007/s10584-006-9173-8.

Xu, H., Sieverding, H., Kwon, H., Clay, D., Stewart, C., Johnson, J.M.F., Qin, Z., Karlen, D.L., Wang, M., 2019. A global meta-analysis of soil organic carbon response to corn stover removal. GCB Bioenergy 11, 1215-1233. https://doi.org/10.1111/ gcbb.12631. 